\title{
Electricity saving in households due to the market liberalization and change in the consumer behaviour
}

\section{Gatis Bažbauers,}

Uldis Bariss,

Lelde Timma ${ }^{\star}$,

Dace Lauka,

Andra Blumberga,

\section{Dagnija Blumberga}

Institute of Energy Systems and Environment, Riga Technical University,

Azenes iela 12/1, Riga, LV-1048, Latvia

E-mail lelde.timma@rtu.lv
In case of opening the electricity market, various factors interact with each other. Although research has been done on various factors affecting the liberal electricity market, little attention has been paid to studying the dynamic relations between the actors involved in the liberal electricity market and projections on electricity consumption in households. The main aim of the research is to explore both short- and long-term effects on the electricity consumption at liberal market conditions by modelling various development scenarios. The electricity market in operation in Latvia was used as the case study. For the simulation of electricity market liberalization, system dynamics has been chosen. This method can determine electricity savings in case of electricity market opening, because system dynamics allows conducting simulation of complex systems and analysing the obtained data to forecast probability of the development of several scenarios. Obtained results show that cumulative electricity savings in households could reach 560 GWh by the end of 2020 due to the opening of the electricity market, implementation of energy saving measures and other reasons. In case of scenario analysis using the change of consumption behaviour, it was obtained that the cumulative electricity saving could be almost twice as big if the majority of households were guided by the environmental concerns. Although the system dynamics model was based on the Latvian case study, its general application to other countries and electricity markets is also possible.

Key words: electricity market, energy systems, innovation diffusion, system dynamics, technological transition

\section{INTRODUCTION}

Directive 96/92/EC [1] concerning common rules for the internal market in electricity, or Electricity Market Directive, set a legal basis for the single electricity market in the EU member states. One of the main guiding principles was to en- sure the competitiveness of this single electricity market.

Since the competiveness is closely related to the price; it was expected that by higher competiveness in the single electricity market, the price of electricity would come down. This assumption was confirmed by several studies, but was not 
valid for all member states. Based on Serralles [2], the average price of electricity in households reduced after the implementation of the Electricity Market Directive; however, some member states experienced the increase in electricity price. According to Ringel [3], the liberalization of the electricity market was followed by the reduction of electricity price, in particular, the drop of electricity price was observed in industry, whereas in households the decrease was lower. The authors argue that the reduction of price is directly associated with the increase of competition, because electricity retailers offered lower price so that consumers would favour their product.

On the contrary, there are also studies that show that a lower electricity price in a liberal market is not always true. Each country may show a different trend, since the internal policy of member states has a greater impact on electricity price than the liberalization of the market itself [4].

These contradictory trends about the electricity price changes in a free market are modelled by Neuhoff and Newbery [5]. In their work, the model that describes the dynamic nature of price changes was presented. The model shows that in the short term the price may increase because of monopolist withdrawal from the market and reorganization of enterprises. This model also includes the market regulator as a separate player where, in the case of electricity market liberalization, the costs for maker regulation may initially increase, thus causing a price increase in the short term.

The price and demand are also linked to price elasticity; the results of Krishnamurthy and Kriström study [6] show high price elasticity in Australia, Canada, Chile, and Spain and a slightly lower one in South Korea and the Netherlands. A study by Ringel [3] notes that the end user is one of the main players in the liberalized electricity market since the time households make their choice of the electricity supplier - either renewable electricity or not, electricity production market is defined.

Of course, in order to define electricity production to a consumer, active participation in required. The report by ECME [7] on the situation in the EU member states after the liberalization of electricity market shows a close correlation $\left(\mathrm{R}^{2}=74.28 \%\right.$, excluding Ireland) between household involvement in choosing the electric- ity supplier and the time that has passed since the liberalization of the electricity market. On average, $1 \%$ of households changed the electricity retailer in the member states where the electricity market opened only after 2007, in contrast to $10 \%$ of households in countries where the market was liberal before 2007. The explanation for this trend is a delay at which the information on several alternatives is being diffused in households. Therefore, a low level of citizen participation in the electricity market is a short-term phenomenon only.

The theory on rebound effect says that if electricity price for end user drops, the electricity consumption will rise. In the EU Commission report on the electricity market liberalization [8], the increase in electricity consumption even by $20 \%$ was forecasted due to lower electricity costs in the liberal market.

As a contrast to the rebound effect, the energy efficiency should also be accounted. The report by ECME [7] shows that the proportion of respondents in all the EU countries who have attempted to reduce their electricity consumption is above $60 \%$. The explanation that both in Latvia and Sweden a similar attitude towards reduction of electricity consumption is observed (about $75 \%$ of respondents tried to reduce their electricity consumption) can be found in work by Papachristos [9].

Papachristos [9] studied household's electricity consumption in relation to the income level of the household. The author divided households into four groups: (1) households that are well informed about electricity prices and focus on energy saving; (2) households that save energy because of the costs and environmental conscience; (3) households that care about the higher comfort and therefore are not interested in energy efficiency; and (4) high-income households with the aim to reduce impact on the environment and therefore investing in energy efficiency. Consequently, there could be various motivations and various income groups willing to reduce the electricity consumption across all member states.

As for now, it has been seen that in a liberal electricity market, various interconnected instruments are in play (for example, price and demand), the activation of some mechanisms has delays (for example, information flow to households), 
and some mechanisms do have a nonlinear nature (for example, public participation in retailer's selection). Therefore, to account for all these factors, a comprehensive modelling tool should be used. System dynamics is one of such tools. System dynamics models allow integrating non-linearities, feedback and delays, thus studying the behaviour of the system under various internal and external factors.

Although it was studied that various factors affect a free electricity market, little attention has been paid to studying the dynamic relations between the actors involved in the liberal electricity market and projections on electricity consumption in households.

As for now, some system dynamics models have been developed to study the electricity market, such as system dynamics model. Arango et al. [10] modelled installed capacity in the electricity market. Vogstad [12] modelled the Scandinavian electricity market under free market conditions and found that the impact on the environment could both decrease and increase. Decrease is observed since at the free market conditions more renewable energy technologies are used, but at the same time increase in demand is observed, which counteracts the emission savings. Ochoa and van Ackere [13] studied British and French interconnection using system dynamics and concluded that in case of a free market cooperation between member states plays an important role.
Moreover, internal policy decisions often cause an unforeseeable effect on the electricity market, thus making the situation worse.

The main aim of the research is to explore both short- and long-term effects on the electricity consumption at liberal market conditions by modelling various development scenarios. For this purpose, a system dynamics model has been built to examine how the physical processes and information flows interrelate in the structure of a dynamic system and how this structure generates dynamic behaviour over time. The electricity market in operation in Latvia was used as the case study.

A hypothesis of the system dynamics model is that introduction of the electricity market will encourage households to undertake energy efficiency measures.

Although the system dynamics model was based on the Latvian case study, its general application to other countries and electricity markets is also possible.

\section{CASE STUDY}

The dynamics of electricity consumption in households based on the electricity consumption group in Latvia is shown in Fig. 1.

As given in Fig. 1, the decrease was recorded in lower electricity consumption groups (consuming less than $1199 \mathrm{kWh}$ ), while a rapid increase was

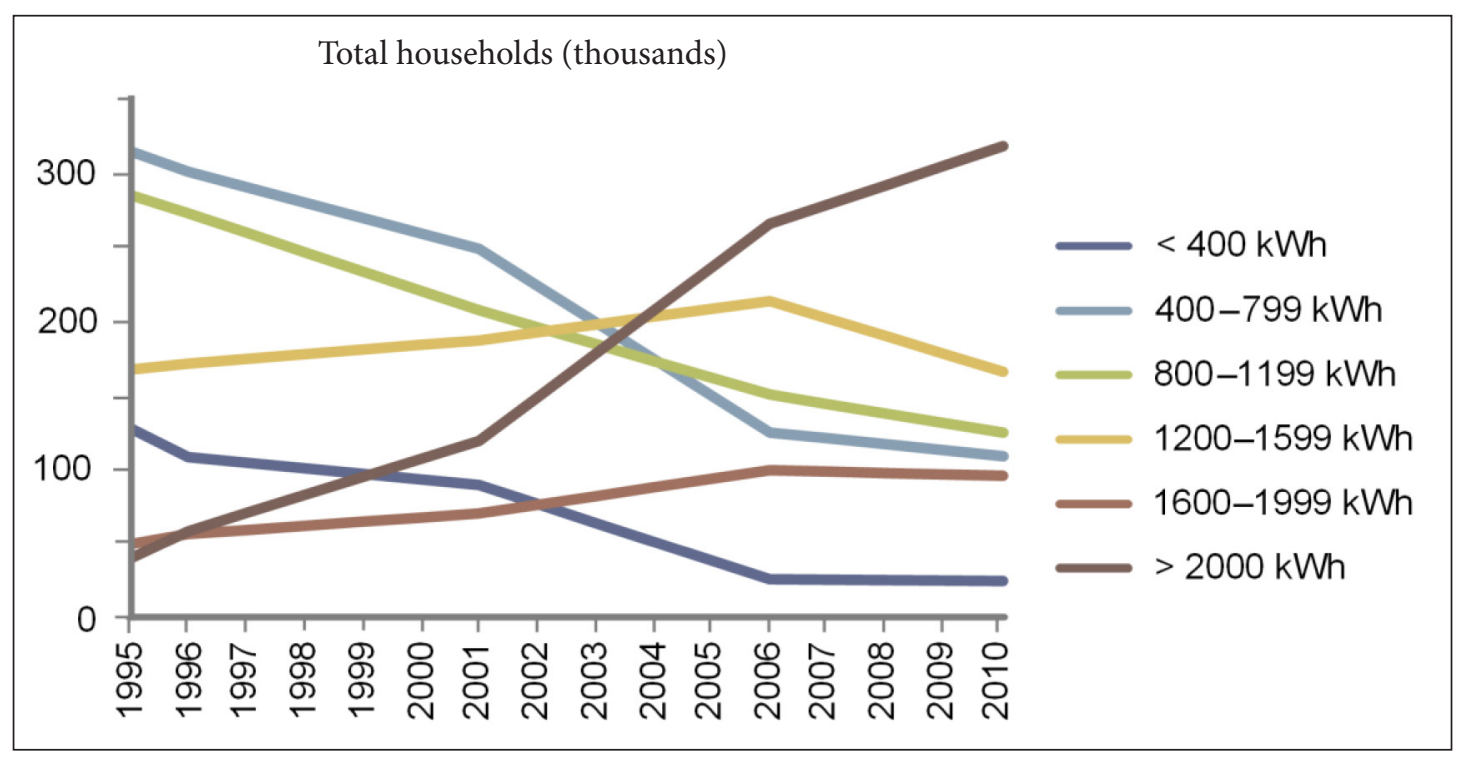

Fig. 1. Dynamics of electricity consumption in households based on the electricity consumption group [11] 
experienced in the group where electricity consumption was above $2000 \mathrm{kWh}$.

The electricity market in Latvia for households opened on the 1st of January 2015. The opening of the electricity market caused an increase in the electricity price in Latvia; the electricity price was lower because it was regulated.

\section{METHODOLOGY}

System dynamics is used to research the behaviour of complex and dynamic systems [14]. Originally, this methodology was developed for directors of companies to help them improve their understanding about manufacturing processes, but now the use of system dynamics has significantly broadened [15].

System's ability to describe delays, for example, information delays, is an essential part in system dynamics [16], since by opening the electricity market, a significant delay arises between the active participation of households in the free electricity market and the official opening date of the electricity market.

The presented system dynamics model distinguishes two groups of households - low- and high-income households. Households' willingness to undertake energy efficiency measures is modelled according to the share of the electricity bill in each household's income.
Electricity consumption is divided into three major groups: (1) lighting, (2) household electrical appliances, and (3) climate control equipment (heating, air conditioning, domestic hot water). The model accounts for the changes in energy efficiency indicators for appliances, influence of welfare on electricity demand (for instance, number of electrical appliances in the household, growth in the living area, etc.) as well as the possible influence of the consumption changes on electricity price, which in turn affects consumption.

In the system dynamics model, the relationship between electricity costs (affected by electricity price and consumption), income (depends on GDP increase) ratio, and part of the household that undertakes electricity saving measures is used. The ratio has been calculated by dividing the average monthly electricity bill by average monthly income in the household. Relationships are derived from the survey data separately for low- and high-income households.

If GDP increases, household welfare improves thereby reducing the ratio between electricity costs and household income, thus accordingly lowering the willingness to save energy, see the causal loop diagram in Fig. 2.

The causal loop diagram in Fig. 2 describes situation when electricity consumption is higher than it could be if electricity saving measures

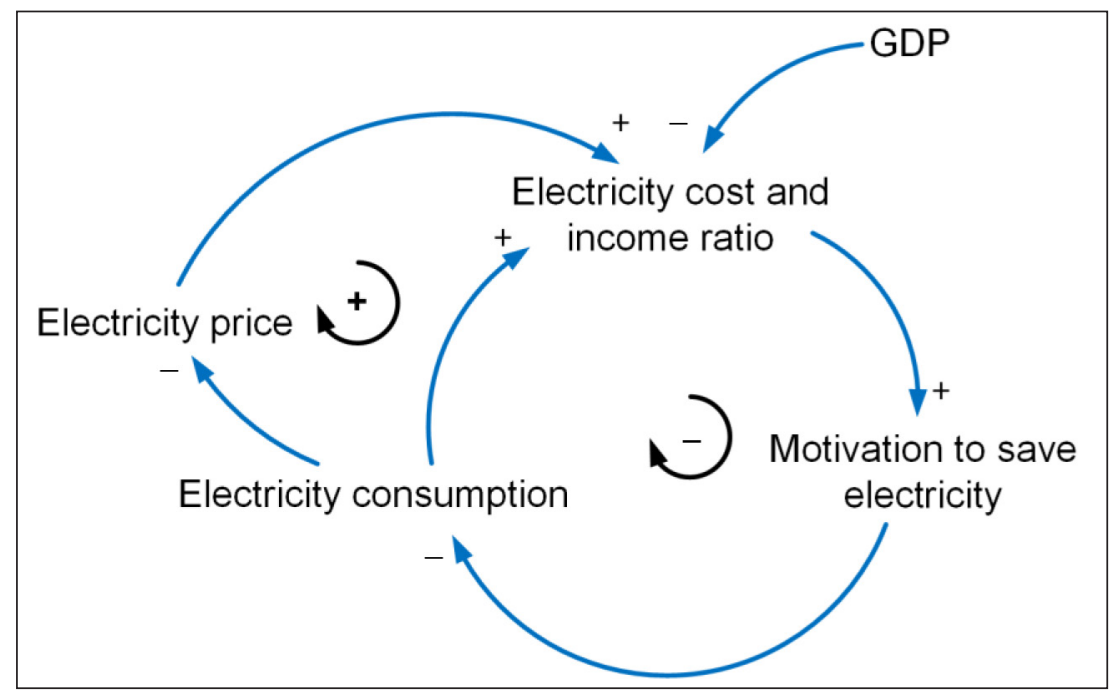

Fig. 2. Causal loop diagram that visualizes relation and feedback between the external parameter GDP and internal parameters, resulting from the parameter electricity consumption and moving towards parameters motivation to save electricity 
were implemented. Higher electricity consumption leads to higher electricity cost and income ratio at a constant electricity price (a negative or balancing loop is formed). On the other hand, electricity consumption also influences electricity price by reducing or increasing average fixed costs per $1 \mathrm{kWh}$ of consumed electricity. Therefore, when electricity consumption decreases, electricity price will increase by increasing electricity cost and income ratio at the constant level of welfare. As a result, motivation to save electricity will increase, thus increasing electricity price even more (positive or reinforcing causal loop is formed).

By increased GDP, the welfare of households rises, resulting in the increase of the living area per 1 household $\left(\mathrm{m}^{2}\right)$ and lighting demand per $1 \mathrm{~m}^{2}$, thus the total demand for lighting growth in households $(\mathrm{lm})$, by increasing electricity consumption. On the other hand, light bulb energy efficiency $(1 \mathrm{~m} / \mathrm{W})$ is rising, thus reducing specific electricity consumption for lighting, see the causal loop diagram in Fig. 3. Electricity cost and income ratio influence motivation to save electricity and willingness to replace current light bulbs with more energy-efficient bulbs and to reduce time when lighting is used (replacement of electric appliances and change of consumption habits), see Fig. 3. By welfare increase (expressed as $G D P$ ), the proportion of low-income households decreases while the proportion of high-income households increases, thus the quantity and usage of electrical appliances increases; at the same time, technological development improves energy efficiency of electrical appliances, thus reducing electricity consumption.

It is assumed that the number of households and the average number of people in a household is constant during the research period. For the simulation, it is assumed that the average electricity price might increase by $30 \%$.

The main sources of data are household survey results and the Central Statistical Bureau of Latvia.

\section{RESULTS AND DISCUSSION}

\section{Structural validation}

Structural validation was performed to validate the model. Structural validation evaluates the reasonableness of the equation within the model and tests the model under extreme conditions.

Validation under extreme values is carried out to determine how calculations change and whether logical and robust results are obtained (for example, fluctuation curves and other unexplainable results are not obtained) by accepting extreme parameter values even though in real life the probability of these values is low.

The aim of this validation is to determine incorrect or inadequate relationship. One of the main

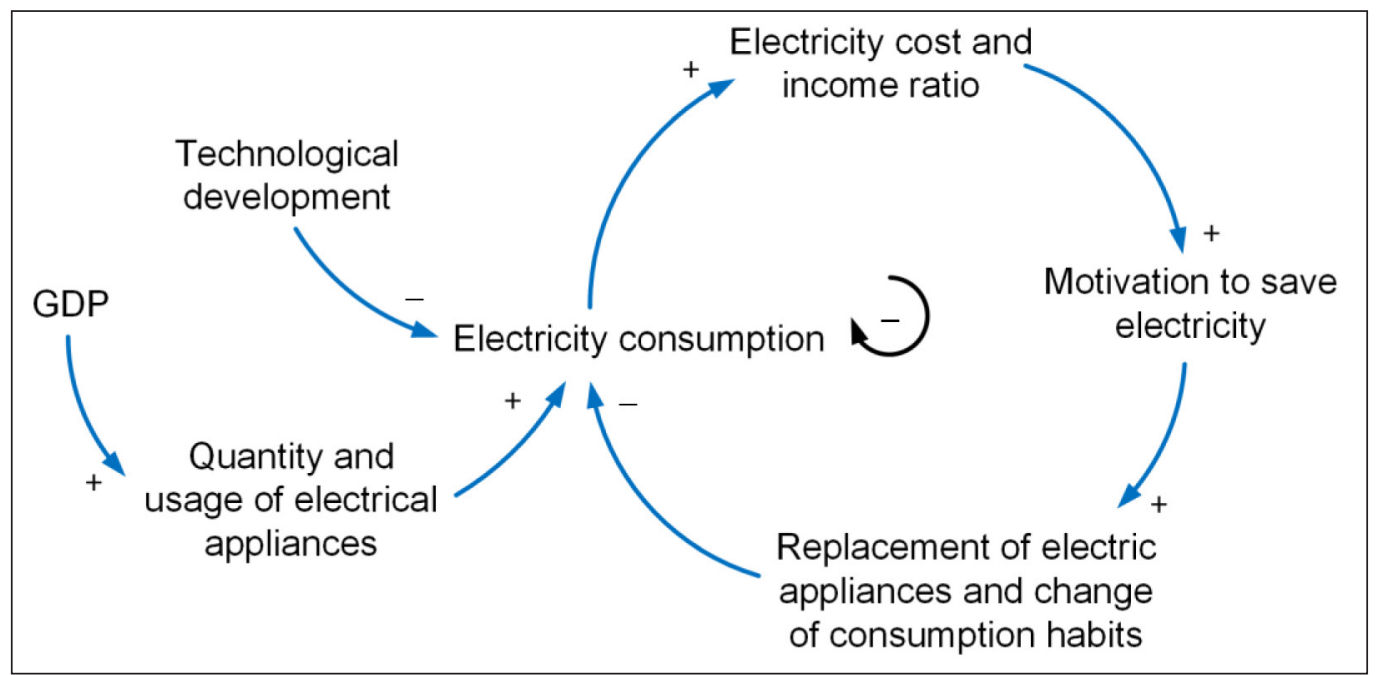

Fig. 3. Causal loop diagram that visualizes interrelation between external parameters like GDP and technological development and internal parameters 
parameters that defines energy saving in households is the dynamics of the replacement of lighting and domestic electrical appliances in households. When the rate of replacement of lighting and domestic electrical appliances is higher, then the reduction of electricity consumption due to replacing of existing appliances with more energy-efficient equipment is greater. The model is tested by convergence of this value close to zero.

The obtained results show that the equations included in the model are reasonable, and the model is robust, without any unpredicted fluctuations, and corresponds to the expected behaviour.

\section{Model behaviour test}

The model behaviour test was conducted to test whether a model created expected future dynamics of behaviour by evaluating various predicted parameters.

One of the main parameters that determine household willingness to save electricity is the ratio between electricity costs and household income. This proportion is affected by electricity price, electricity consumption, and household income. It is expected that if income increases, the willingness to save electricity will reduce if other conditions remain constant.

The results of the model behaviour test under the circumstances when household income becomes twice bigger are given in Fig. 4 .

Results in Fig. 4 confirm that if household income increases, willingness to save energy lowers.
Scenario analysis using replacement of electric appliances

With the help of a system dynamics model, possible electricity consumption changes and accumulated electricity savings between 2014 and 2020 according to three scenarios (base, conservative, and optimistic) have been evaluated.

Analysis of scenarios is based on these assumptions:

- the base scenario is a reference scenario with basic assumptions,

- in the conservative scenario, time in which part of the population replaces electrical appliances is increased by $10 \%$,

- in the optimistic scenario, time in which part of the population replaces electrical appliances is decreased by $10 \%$.

The base scenario is a reference scenario with basic assumptions in which it is stated that cumulative electricity savings in the household sector between 2014 and 2020 are 560 GWh, see Fig. 5 .

In the conservative scenario, time in which part of the population replaces electrical appliances is increased by $10 \%$. As a result, it is obtained that electricity savings in the household sector between 2014 and 2020 are 543 GWh (Fig. 5), which is by about $3 \%$ less than in the base scenario.

In the optimistic scenario, time in which part of the population replaces electrical appliances is reduced by $10 \%$. As a result, it is obtained that electricity savings in the household sector between 2014 and 2020 are $581 \mathrm{GWh}$, which is by about $4 \%$ more than in the base scenario.

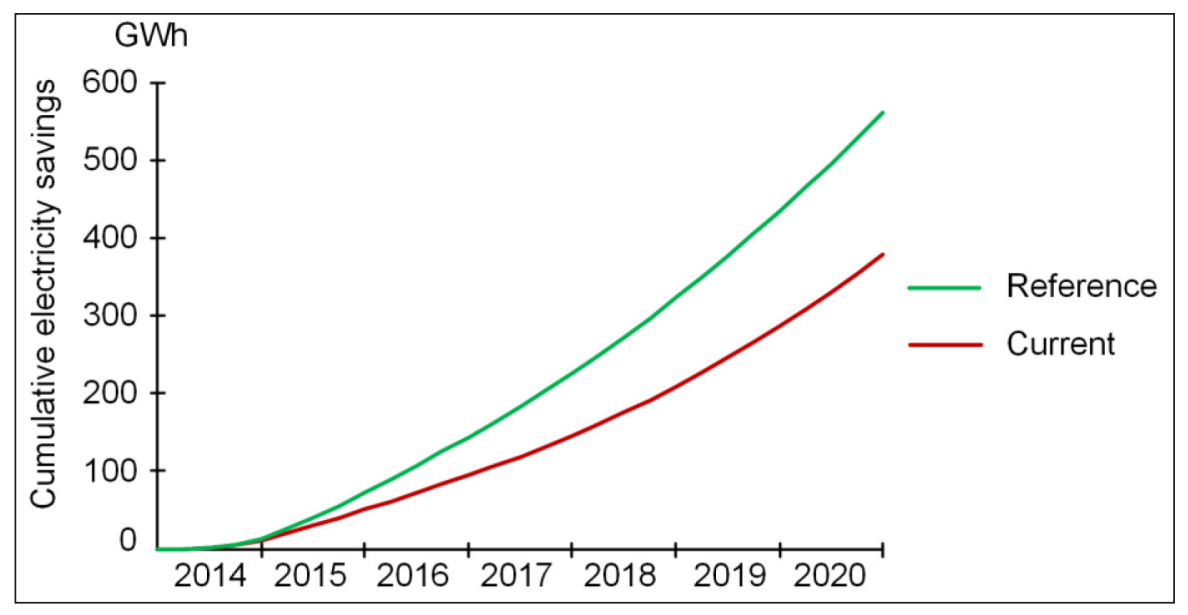

Fig. 4. Comparison of cumulative electricity saving dynamics between calculations conducted for the base scenario (reference) and the scenario in which household income increased twofold (current) 


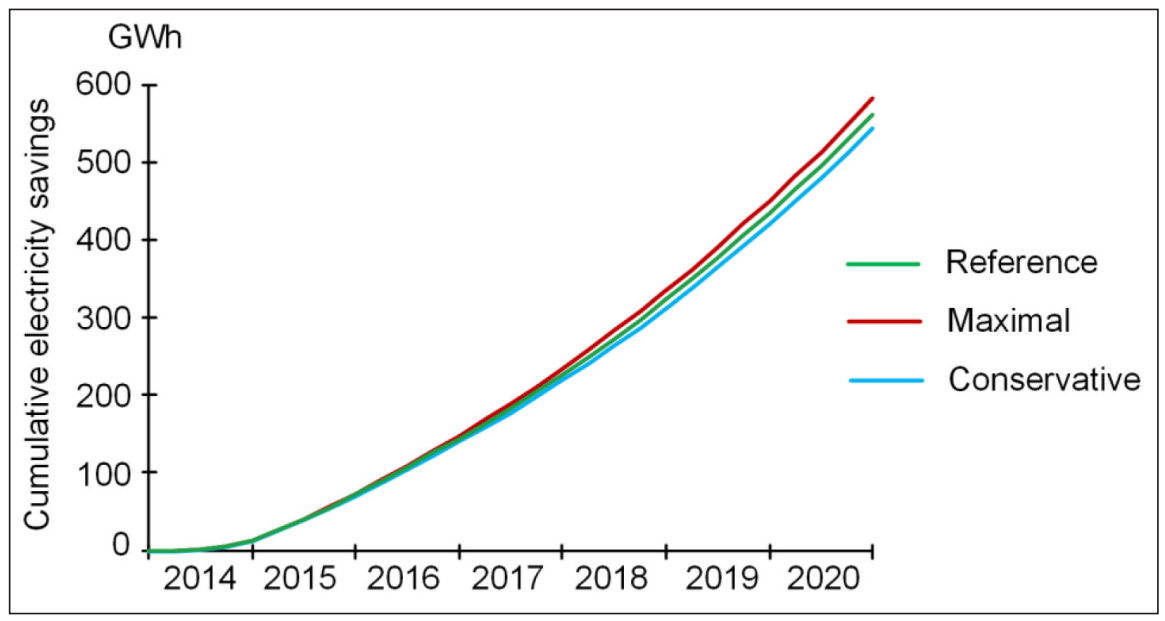

Fig. 5. Dynamics of household cumulative electricity savings in base (reference), conservative (conservative), and optimistic (maximal) scenarios

Therefore, in case of price reduction, a number of risks exist for achieving energy savings. Firstly, increasing consumption leads to a greater production of electricity. Secondly, by reducing electricity price for the end user, support for energy management is reduced, because savings may not cover the cost of introduced measures. Finally, price reduction hinders the implementation of policy objectives in the field of energy efficiency. To achieve the objectives, tax should be increased to compensate electricity price reduction, but mostly, such political decision is not adopted [3].

The producer can provide a lower electricity price, when the ratio between fixed and variable prices is restructured. Moreover, the producer offers a lower price, when energy demand is low; this correspondingly increases electricity production; therefore, electricity retailer mostly is not interested in decline of demand and customer management program.

On the other hand, competition for the lowest price forces companies to reduce their production costs. Costs can be decreased by undertaking energy efficiency measures in power plants as well as by reducing electricity losses during distribution and transportation. Electricity market liberalization in these circumstances is beneficial to decentralized, high-efficiency energy production located close to the end user. Energy production is especially advantageous by combining it with the use of renewable energy resources.

In case of a free electricity market, power plants that utilize renewable energy resources and whose efficiency is high acquire knowledge about the market much faster than in a regulated market, because all the electricity suppliers should be provided with open access to electricity distribution and transmission networks. On the other side, when efficient small power plants cover part of the cogeneration plant power (cogeneration plants usually operate at low power modes or even at condensing mode), cogeneration plants may become uncompetitive [3].

\section{Scenario analysis using change of consumption behaviour}

In case of scenario analysis targeted at consumption behaviour, the simulations were carried out to find out how results may differ if households save electricity for the environment reasons or guided by costs (gains). Three theoretical cases were created:

1) base scenario (under the same conditions as in the chapter on model's behavioural test);

2) optimistic scenario, in which half of the households take part in electricity saving due to environmental concerns, and half due to gains;

3) pessimistic scenario, in which $80 \%$ take action due to gains, but the remaining $20 \%$ due to environmental concerns.

This division of households into environmentally motivated and motivated by economic gains is based on the hypothesis of authors. Nevertheless, this division can be supported by a study by Schwarz and Ernst [17] on the diffusion of environmental innovations in Germany. 
The authors use the methodology of aggregated lifestyles adopted from Sinus-Milieus ${ }^{\oplus}$ models [18], where consumers are divided into various social groups. This study found out that around $20 \%$ of consumers could be regarded as Social Leaders. Based on the presented case study [17], it is assumed that the pessimistic scenario in this work would correspond to the market situation where Social Leaders take the role of environmentally motivated households and therefore account for about $20 \%$ of the population. This assumption is also supported by the consumer survey of the largest electricity trader in the Baltic, Latvenergo AS, where $50 \%$ of respondents were motivated to save electricity due to economic reasons, and $13 \%$ due to environmental reasons. It should be noted that sample size was only 375 respondents from Riga city and its neighbouring regions; therefore, these results may be biased.

In case of the optimistic scenario, it is assumed that Social Leaders have motivated other groups of the population to start saving due to environmental concerns; thus, the hypothesis of $50 \%$ motivated by environmental concerns is obtained. The optimistic scenario is motivated by the fact that the Sinus-Milieus ${ }^{\oplus}$ models capture the roles of consumers for one specific product and specific time and location; however, the role of these consumers can change over time. Based on the results of Special Eurobarometer 435 [19], climate change is regarded as the 4th most serious problem, where the economic situation was mentioned as the 3rd most serious problem with just one percentage point difference. Therefore, the economic situation and climate change could be attributed to the problem with the same magnitude for Europeans. In some countries, climate change is regarded as the most serious concern, based on public survey conducted in 2015; these are Sweden, where close to $40 \%$ of respondents were concerned about the climate change as the most serious problem, followed by Denmark with $30 \%$, and Finland with $26 \%$.

Therefore, this optimistic scenario is based on the assumption that climate concerns will continue to grow, since the variability in climate is projected to increase.

With gains, those households (groups of lowand high-income households) that mainly undertake energy efficiency measures due to increase in the ratio between electricity costs and income are understood. These households can be referred to as "economic households". Data obtained from the Marketing and Public Opinion Research Centre shows how the proportion of households that are carrying out energy efficiency measures changes if the ratio between electricity costs and income increases. Moreover, there are households that will never undertake energy efficiency measures even if the ratio between electricity costs and income increases (at least within the range that has been considered).

Other part represents the so-called "environmental households". These households take action due to environmental concerns. Unfortunately, no statistical data are available on the factors that influence the behaviour of these households. Therefore, in the model it is assumed that with a fixed time constant, those environmental households that do not take part will become households that take action for the environment. The time constant is lower when action does not require large investments, for example, changing habits with the use of lighting devices. In contrast, time constant is higher when lighting devices have to be replaced, and even higher if the electrical appliances need to be changed. In order to take action, time is required (for instance, time is needed for obtaining information or saving money for energy efficiency measures, etc.), but no specific information is given on how and which factors might influence this time constant. Perhaps, it would be difficult to determine the time constant due to different behaviour of human action and wellbeing. Therefore, it can be considered that in the model, the mechanism of action is observed, but precise numerical characteristic is not known.

Results given in Fig. 6 show intuitively predictable results.

If "environmental households" that act independently of the ratio between electricity price and income are separated from other households, then savings are higher than in the base scenario (in the base scenario, all the households act like "economic households"). This is only possible if "environmental households" take action faster than "economic households". Furthermore, if the proportion of "environmental households" increases, savings become greater. 


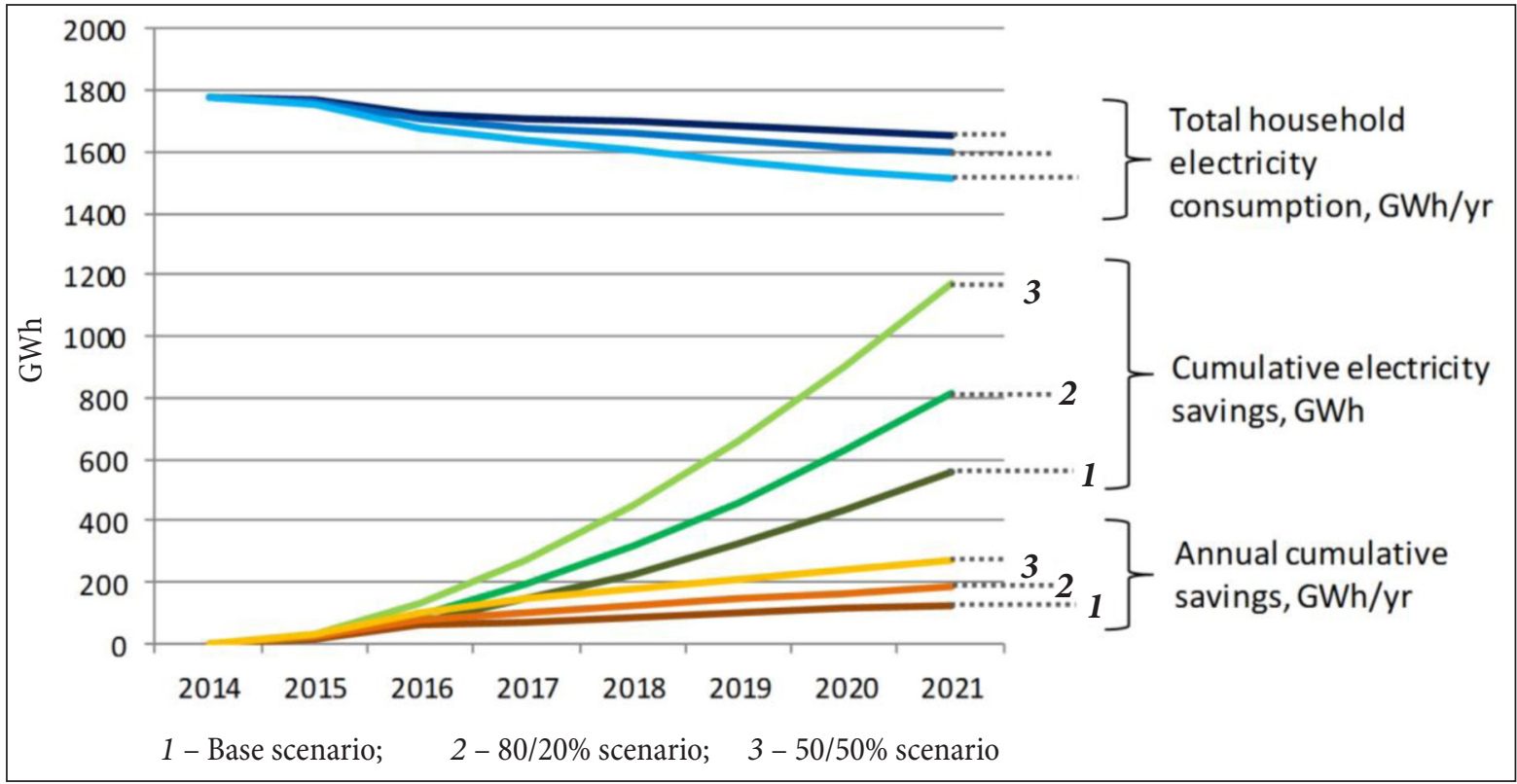

Fig. 6. Dynamics of household electricity consumption and annual cumulative electricity savings in scenario analysis using change of consumption behaviour

The bottleneck of the research is that among "economic households" for which survey data from the Marketing and Public Opinion Research Centre are available are also "environmental households". Households have probably done energy efficiency measures due to several motives, but the only motive observed in this research is the ratio between electricity costs and income. In addition, it is not known how "economic" and "environmental" households would actually act if separate data from each household were obtained.

\section{CONCLUSIONS}

In case of opening the electricity market, various factors interact with each other. During electricity market liberalization, it is important to know which market structure mechanisms will be used and what will be the number and proportion of suppliers thereof decrease as well as increase in price level is possible in the short term.

Benefits of electricity market opening dominate over drawbacks, as new suppliers that will provide energy-efficient solutions for the production of electricity as well as conduct energy consumer management measures emerge into the market. They will also change the market structure and supply to the consumer. Electricity will be offered not only based on the lowest price but also on several factors like environmental, resource and waste aspects. Consequently, in the long term, the main player in the market is the electricity consumer, whose choice will determine to what extent the potential of renewable energy will be used.

For the simulation of electricity market liberalization, system dynamics has been chosen. This method can determine electricity savings in case of electricity market opening, because system dynamics allows conducting simulation of complex systems and analysing the obtained data to forecast probability of the development of several scenarios.

Obtained results show that cumulative electricity savings in households could reach $560 \mathrm{GWh}$ by the end of 2020 due to the opening of the electricity market.

In case of scenario analysis using the change of consumption behaviour, it was obtained that the cumulative electricity saving could be almost twice as big if the majority of households were guided by the environmental concerns.

\section{ACKNOWLEDGEMENTS}

The work has been supported by the National Research Program "Energy-efficient and low-carbon 
solutions for a secure, sustainable and climate variability reducing energy supply (LATENERGI)".

Received 1 December 2015 Accepted 15 December 2015

\section{References}

1. Directive 96/92/EC of the European Parliament and of the Council of 19 December 1996 concerning common rules for the internal market in electricity. Official Journal L 027, 30/01/1997 P. 0020-0029.

2. Serrallés R. J. Electric energy restructuring in the European Union: Integration, subsidiarity and the challenge of harmonization. Energy Policy. 2006. Vol. 34. No. 16. P. 2542-2551.

3. Ringel M. Liberalising European electricity markets: Opportunities and risks for a sustainable power sector. Renewable and Sustainable Energy Reviews. 2003. Vol. 7. No. 6. P. 485-499.

4. Moreno B., López A. J., García-álvarez M. T. The electricity prices in the European Union. The role of renewable energies and regulatory electric market reforms. Energy. 2012. Vol. 48. No. 1. P. 307-313.

5. Neuhoff K., Newberry D. Evolution of electricity markets: Does sequencing matter? Utilities Policy. 2015. Vol. 13. No. 2. P. 163-173.

6. Krishnamurthy C. K. B., Kriström B. A crosscountry analysis of residential electricity demand in 11 OECD-countries. Resource and Energy Economics. 2015. Vol. 39. P. 68-88.

7. The Functioning of Retail Electricity Markets for Consumers in the European Union. Final Report. ECME Consortium, 2010.

8. Communication from the Commission to the Council and the European Parliament: completing the internal energy market. COM/2001/125 final. Brussels: EU, 2001.
9. Papachristos G. Household electricity consumption and $\mathrm{CO}_{2}$ emissions in the Netherlands: A model-based analysis. Energy and Buildings. 2015. Vol. 86. P. 403-414.

10. Arango S., Smith R. A., Dyner I., Osorio S. A system dynamics model to analyze investments in power generation in Colombia. Proceeding of the 20th System Dynamics Conference, July 28 - August 1, 2002, Palermo, Italy. P. 1-18.

11. Central Statistical Bureau of Latvia, Databases. Available: www.csb.gov.lv/en

12. Vogstad K. Counterproductive environmental policies: Long term versus short term substitution effects of natural gas in a liberalised electricity market. Proceedings of the 22nd System Dynamics Conference Proceedings, July 25-29, 2004, Oxford, England. P. 1-33.

13. Ochoa C., van Ackere A. Winners and losers of market coupling. Energy. 2015. Vol. 80. P. 522-534.

14. Forrester J. W. Industrial Dynamics. Cambridge: MIT Press, 1961.

15. Blumberga A. (Ed.) Blumberga D., Bažbauers G., Davidsen P., Moxnes E., Dzene I., Barisa A., Žogla G., Dāce E., Bērziṇa A. System Dynamics for Environmental Engineering Students. Riga: RTU VASSI, 2011.

16. Ford A. Modeling the Environment. An Introduction to System Dynamics Models of Environmental Systems. Washington: Island Press, 1999.

17. Schwarz N., Ernst A. Agent-based modeling of the diffusion of environmental innovations - An empirical approach. Technological Forecasting and Social Change. 2009. Vol. 76. No. 4. P. 497-511.

18. Sinus Markt und Sozialforschung, Sinus-Milieus ${ }^{\circledast}$. Available: http://www.sinus-institut.de/en/.

19. Special Eurobarometer 435. Report. Climate Change. European Union, 2015. 
Gatis Bažbauers, Uldis Bariss, Lelde Timma, Dace Lauka, Andra Blumberga, Dagnija Blumberga

\section{ELEKTROS ENERGIJOS DE்L RINKOS}

LIBERALIZAVIMO VARTOTOJŲ ELGSENOS KAITOS SUTAUPYMAS NAMŨ ŪKIUOSE

\section{Santrauka}

Vykdomi įvairių veiksnių, turinčių ittakos laisvos elektros energijos rinkai, tyrimai, tačiau iki šiol mažai dèmesio skirta dinaminiams ryšiams tarp laisvos elektros rinkos dalyvių ir elektros energijos suvartojimo namų ūkiuose nagrinèti. Pagrindinis tyrimo tikslas - ištirti tiek trumpalaikį, tiek ilgalaiki poveiki elektros energijos suvartojimui laisvos rinkos sąlygomis, modeliuojant îvairius plètros scenarijus. Elektros rinka, veikianti Latvijoje, buvo panaudota kaip tyrimo atvejis. Modeliuojant elektros energijos rinkos liberalizavimą pasirinktas sistemos dinamikos metodas, leidžiantis nustatyti sutaupytos elektros energijos apimtis elektros rinkos atvèrimo atveju, nes sistemos dinamika leidžia atlikti sudètingų sistemų modeliavimą ir analizuoti gautus duomenis bei prognozuoti kelių raidos scenarijų tikimybę. Gauti rezultatai rodo, kad iki 2020 m. pabaigos sukauptas namų ūkiuose sutaupytos elektros kiekis gali pasiekti $560 \mathrm{GWh}$ (dèl elektros energijos rinkos atvérimo, energijos taupymo priemonių igyvendinimo ir kitu priežasčių). Scenarijų analizès atveju, naudojant vartojimo elgsenos kaitą, nustatyta, kad sukauptas sutaupytos elektros kiekis gali būti beveik dvigubai didesnis, jei dauguma namų ūkių vadovautųsi aplinkosaugos priemonemis. Nors sistemos dinamikos modelis buvo grindžiamas Latvijos atvejo tyrimu, taip pat galimas bendras jo taikymas kitoms šalims ir elektros rinkoms.

Raktažodžiai: elektros rinka, energijos sistemos, inovacijų sklaida, sistemos dinamika, technologiniai pokyčiai 